\title{
Erythroid Neoplasm
}

National Cancer Institute

\section{Source}

National Cancer Institute. Erythroid Neoplasm. NCI Thesaurus. Code C7064.

A neoplasm affecting cells of the erythroid lineage. 